\title{
Preserving of Traditional Culture Expression in Indonesia
}

\author{
Ayu Citra Santyaningtyas ${ }^{1} \&$ Mahmood Zuhdi Mohd Noor $^{2}$ \\ ${ }^{1}$ University of Jember, Jember, Indonesia \\ ${ }^{2}$ National University of Malaysia, Kuala Lumpur, Kuala Lumpur, Malaysia \\ Correspondence: Ayu Citra Santyaningtyas, University of Jember, Jember, Indonesia. E-mail: \\ santyablue@yahoo.com
}

Received: April 20, 2016 Accepted: May 4, 2016 Online Published: June 21, 2016

doi:10.5539/ass.v12n7p59 URL: http://dx.doi.org/10.5539/ass.v12n7p59

\begin{abstract}
The great nation is a nation that is able to uphold the identity of the nation. Indonesia as the country with works of art and culture is no exception in terms of the traditional cultural heritage indeed has tremendous potential. And this potential still seems to be hidden and not used optimally.

One of the potential that can be developed for economic development are traditional knowledge (traditional knowledge), including folklore, art, dance, carvings, weavings and other traditional cultural expressions is the result rather than the fruit of human thought both movable and captured by our senses that have either abstract or tangible form.

The emergence of issues of injustice felt by developing countries occur because of traditional cultural expressions they do not get the protection and respect for traditional communities as the owners of traditional cultural expressions. Utilization of traditional cultural expressions may be defined as the use of traditional cultural expressions assets commercially and used without any sharing of benefits from the developed countries, therefore we need a protection.
\end{abstract}

Keywords: preserving, traditional culture expression, Indonesia

\section{Introduction}

Indonesia is occupied with 33 provinces (Note 1) with different ethnic expressions and various traditional cultures. The richness of traditional culture expressions and traditional culture legacies must be quite precious to be national identity and also important to support economic development in Indonesia. Either traditional culture expressions or traditional culture legacies have grown from various activities and creativities of indigenous people who settle into Indonesia regions with their distinctive features.

Traditional culture expressions and traditional culture legacies have been admitted as the developed countries as their asset without receiving legal consent from Indonesia. Therefore, the question is "How can Indonesia protect its traditional culture expressions and traditional culture legacies?"

\section{Defining Traditional Culture Expressions}

In term of etymology, Traditional Culture Expressions involve three words, respectively tradition, culture and expression. For "expression", it means as to reveal or to declare certain purpose, idea or feeling. Culture in English is similarly as "budaya" in Indonesian (Note 2). The word "budaya" itself roots from Sanskrit "budhayah" meaning as thought or intellectuality (Note 3 ). In general, culture may be defined as a something produced by the thought and intellectuality of humans when they develop and maintain their life within their environment. Traditional culture expressions become a part of the cultural life with the community as the owner of culture. Traditional culture expressions contain several values such as economic, spirituality and communality. All these values are respected by traditional community. Therefore, traditional culture expressions can represent the identity of indigenous community in a certain region (Note 4).

Traditional Culture Expressions as already stated in Article 8 A on Traditional Knowledge, Innovation and Preliminary Practice, can be described as follows: "Traditional knowledge refers to the knowledges, innovations and practices of indigenous and local communities in the world that develop from their experience through centuries. Traditional knowledge can be transferred orally through generations. It is a collective asset possessed and managed through several forms such as folktales, folk songs, proverbs, cultural values, faiths, rituals, 
community laws, local languages, and animal descendants (Note 5).

Traditional knowledge is also useful in several fields that very important to community life such as agriculture, fishery, health, horticulture, and forestry. An idea is then highlighted by UNESCO (United Nations of Education, Science and Culture Organization) by organizing a convention aimed to protect traditional culture expressions. This Convention is called as the Convention of Cultural Sanctuary Object (the Convention of Protection for Cultural Legacies). Sports, expressions, knowledges and skills advocated throughout times by communities, groups and/or in specific cases, by individuals, are usually claimed by them as their cultural legacies. The Convention attempts to regulate such claim by explaining intangible cultural legacies. Intangible cultural legacies may include practices, representations, expressions, knowledges, and skills - also tools, objects, artifacts and cultural spaces - considered by communities, groups and/or in several cases, individuals, as their cultural legacies.

In this Convention, knowledge does not have explicit meaning because the meaning of knowledge domain is still subsumed into "knowledges and practices relevant to nature and universe" (Note 6). In other words, knowledge still lacks of concrete definition. Proper knowledge relevant to skills or practices that benefit nature and universe often remains within a separate domain. The domain that manifests traditional culture expressions includes (Note 7):

1. Traditional or oral expressions.

2. Art performances.

3. Social habits, rituals and ceremonies.

4. Knowledges and skills related to nature and universe.

5. Traditional handicrafts.

According to WIPO, traditional culture expressions (or expressions from folktales) may include music, art, design, name, sign, symbol, appearance, architecture, handicraft and narration. WIPO defines traditional knowledge as the category containing people expressions such as music, dance, song, handicraft, design, narration, and art work". The Convention and WIPO have used this definition to elaborate cultural characteristic comprising of cultural sanctuary objects. Any objects included into traditional culture expressions are those that (Note 8):

1. Can be inculcated and transferred through generations;

2. Can develop dynamically; and

3. Can be managed consistently to community identity.

Pursuant to these characteristics, traditional culture expressions can be seen as cultural sanctuary objects. Main goal of the Convention of Cultural Sanctuary Object is to preserve cultural legacies. The protection meant by the Convention is not "protection for security". Based on Article 2 (3), protective steps to ensure the preservation of cultural sanctuary objects are supported by the quote: "The protection is considered as the measure used to ensure the viability of intangible cultural legacies and communal creativities" (Note 9).

\section{Stealing Against Traditional Culture Expressions}

Indonesia is known with abundance of traditional culture expressions and traditional culture legacies. Diversity is quite prominent because various ethnics live in Indonesia and bring along with them higher level of art creativities and traditional culture expressions. Moreover, traditional culture expressions are the product of human thoughts, either in abstract/intangible or tangible forms, which can be transferred and captured by human senses (Note 10).

Injustice issue has forced developing countries into discomfort because their traditional culture expressions are not given adequate protection. Indigenous/traditional peoples as the owner of traditional culture expressions may then feel disrespected.

Esmi Warasih has suggested that regulatory measures must be taken because it can undergo several functions as dispute resolution, social control, social engineering, community emancipation, legitimacy structure, change control and also distributive structure (Note 11).

Illegal utilization of assets of traditional culture expressions can be defined as using assets of traditional culture expressions and intellectual property rights for commercial interest to empower the existence of other traditional culture expressions but through a non-mutual partnership system (Note 12). However, the utilization of Indonesia traditional culture assets by other parties or developed countries is very restless recently. As indicated 
within electronic media, the utilization of assets of traditional culture expressions is not only undergone by foreign entrepreneurs, but also by some developed countries. Illegal utilization of assets of traditional culture expressions has caused traditional citizens into disappointment. It raises a question about governmental action to protect communal assets of traditional culture expressions. The appraisal about the protection of traditional culture expressions may be quite relevant with one academic effort to understand protection issues. This research is then aimed to understand traditional culture expressions in Indonesia to improve people economic development and also to look for protective measures for traditional culture expressions itself.

The number of assets of Indonesia traditional culture expressions that claimed by developed countries is ironically enormous. It includes cultural objects such as batiks, ancient manuscripts, culinary recipes, songs, dances, music tools, designs, plant products, and others. Worse, the utilization has taken place for several decades. Data of assets of traditional culture expressions claimed by other countries are explained as follows (Note 13):

\begin{tabular}{|c|c|c|}
\hline No. & Cultural Objects Claimed & Countries That Use Traditional Culture Expressions \\
\hline & Batik & Adidas \\
\hline & Batik Pesisir & China \\
\hline & Rendang & Holland \\
\hline & Sambal Bajak & Holland \\
\hline & Sambal Petai & Holland \\
\hline & Sambal Nanas & Holland \\
\hline & Jepara Graving & French \\
\hline & Tempe & Thailand \\
\hline & Jepara-Distinctive Ornamental Frame & England \\
\hline & Bali Silver Handicraft & America \\
\hline
\end{tabular}

The list above has indicated that several developed countries have utilized Indonesian traditional culture expressions. The assets of traditional culture expressions as the property rights, the rights for work creations, or the rights for cultures, are definitely national resources. It is also the base capital that can be engineered to improve welfare and life quality, and also meaningful to produce better life.

Global phenomenon, in one side, represents a big chance for Indonesian to show their creativities by introducing products from traditional culture expressions. In other hand, however, if traditional peoples themselves do not respect their cultural assets and lack of appreciation to it, there will be a possibility that the forward-looking countries with creativities will be eager enough to utilize such abandoned cultural assets, and even to claim these assets as "their rights of cultures". Cultural globalization is a phenomenon that shall given opportunity for Indonesian to show their pride, respect, and love to their products of traditional culture expressions.

\section{SafeguardingTraditional Culture Legacies in Indonesia}

According to Professor Coombe, "most indigenous peoples in the world" have depended on their traditional knowledges, traditional culture expressions, traditional culture legacies, biological diversities, agricultures, and important materials for life feasibility (Note 14). One method to preserve traditional culture expressions as intangible culture legacies is through preservation and conservation. John Merryman asserts that the most important policy advocated by indigenous peoples is that traditional culture expressions are produced by ancestors for the life feasibility of indigenous peoples itself. In certain perspective, particularly from the developed countries, preserving the object of traditional culture expressions is not preservation described by our reasoning (Note 15).

Safeguarding traditional culture expressions must involve individuals, communities and government, or even the nation. Henry Merryman adds that nationalism and internationalism of traditional culture expressions does not need exclusive theories. The point is that the contemporary world must find better way to put traditional culture expressions into a legal standing, perhaps through laws and regulations. Such action may contribute greatly to the policies that position traditional culture expressions into local, national and international establishments. However, Henry Merryman does not identify the model needed to develop the theory. Henry Merryman's 
opinions only highlight the cooperation system between nationalism and internationalism that must be developed to protect traditional culture expressions by recording and documenting the existing traditional culture expressions (Note 16).

The process of recording and documenting traditional culture expressions in Indonesia has been in pursuance of Article 37 of Law No.11/2010 about Cultural Legacies. It aims to respect cultural nationalism to produce better integration; it also helps to explain the origin of national histories and traditional culture expressions in Indonesia, especially the teaching about some cultural and art values that successfully preserved. Henry Merryman also states that the protection of traditional culture expressions shall be focused on preserving the original form of traditional culture expressions because this form may still have distinctive quality as the irreplaceable source. This focus may be useful in understanding the concept of traditional culture expressions as national cultural legacies because the legacies represent the manifestation of nationalism and cultural property of a nation where peoples and government play great role to preserve values in traditional culture expressions. Maria Aurora Fe Candelaria declares that a nation must take necessary action as the supporter to the sovereignty and ownership of traditional culture expressions because (Note 17):

1. The property of traditional culture expressions is the expressions of a civilization that must exist or grow in a nation and thus, the citizens have a strong right to keep it as their national pride.

2. The retention of national sovereignty is needed to protect traditional culture expressions in proper quality, including the economic values that can be used by citizens.

Kanchana Wangkeo concedes that a tension between nationalism and internationalism of culture for the interest of traditional culture expressions is also one of cultural legacies that in turn, will be human collective legacies (Note 18). The object of traditional culture expressions is then considered as public resources, like water or air. Therefore, resources are then used for collective interest, not only for the interest of indigenous peoples. Public shall be given an access to these resources and the cost must be paid by those with such access. However, the nation must still be responsible to protect the property of traditional culture expressions, and it is not surprising if the preservation is directly conflicted with the base principles of international law, such as national sovereignty rights and non-intervention rights.

\section{Conclusion}

Indonesia has been known as a nation with remarkable artistic works and traditional cultures. Traditional culture expressions in Indonesia have been so vary because many ethnics are living in Indonesia with higher level of artistic creativities and traditional culture expressions. Developed countries have used Indonesian traditional culture expressions without permission and it causes a sense of injustice to the position of indigenous peoples as the owner of traditional culture expressions.

The sense of injustice felt by the developing countries, including Indonesia, is too apparent, but traditional culture expressions are still neglected without adequate protection and respect, and so are indigenous peoples as the owner of traditional culture expressions. Therefore, a protection by a nation or international community is definitely needed. The protection by a nation is called defensive protection and can be done by registering and documenting traditional culture expressions. Documenting traditional culture expressions must be very important to preserve the knowledge for future generations and to protect the knowledge as intellectual property asset.

\section{References}

Aulia, M. Z. (2006). Perlindungan Hak Kekayaan Intelektual atas Pengetahuan Tradisional. Jakarta: FH UI.

Bainbridge, D. (1999). Intellectual Property, Financial Times. Pitman Publishing, England.

Candelaria, M. A. F. The Angkor Sites of Cambodia: The Conflicting Values of Sustainable Tourism and State Sovereignty. BROOK. J. INT'L L., 253.

Citrawinda, C. (2003). Hak Kekayaan IIntelektual-Tantangan Masa Depan, Jakarta Badan Penerbit Fakultas Hukum Universitaas Indonesia.

Coombe, R. J. (2005). Protecting Traditional Environmental Knowledge and New Social Movements in the Americas: Intellectual Property, Human Right, or Claims to an Alternative Form of Sustainable Development? Florida J Intl L, 17(115).

Damayanti, E. (2002). Hukum Merk Tanda Produk Industri Budaya. PT. Alumni.

Damian, E. (2009). Hukum Hak Cipta, PT Alumni, Bandung.

Djubaedillah, M. D. dan R. (1997). Hak Kekayaan Intellektual, Sejarah, Teori dan Praktiknya di Indonesia, PT. 
Citra Aditya Abadi, Jakarta.

Drahos, P. (2007). Thinking strategically about intellectual property rights. World Patent Information, 29.

Dutfield, G. (2004). Intellectual Property, Biogenetic Resources and Traditional Knowledge. Earthscan, UK.

Dutfield, G. Protecting the Rights of Indigenous People; Can Prior Informed Consent Help? (Chapter 4).

Hadikusuma, H. (2010). Pengantar Hukum Adat, Jakarta, Mandar Maju.

Hamzah, M. G. (2004). Peranan Hukum Dalam Upaya Pelestarian Warisan Budaya. Jurnal Ilmu Hukum Amannagappa, 12(3).

Heald, P. J. (2003). The Rhetoric of Biopiracy. Cardozo J Intl \& Comparative L, 519.

Ikhromi, T. O. (2010). Pokok-Pokok Antropologi Budaya, Jakarta, Yayasan Obor Indonesia.

Kintner dan Jack Lahr, E. W. (1983). An Intellectual Property Law Primer. Clark Boardman, New York.

Koentjoroningrat. (2009). Pengantar Ilmu Antropologi, Rineka Cipta, Jakarta.

Kusumadara, A. (2011). Pemeliharaan dan Pelestarian Pengetahuan Tradisional dan Ekspresi Budaya Tradisional Indonesia: Perlindungan Hak Kekayaan Intelektual dan Non-Hak Kekayaan Intelektual. Jurnal Hukum, $18(1)$.

Lewinski, S. (2004). Indigeneous Heritage and Intellectual Property: Genetic Resources. Traditional Knowledge and Folklore, Kluwer Law International.

Lewinski, S. V. (2003-2004). The Protection of Folklore, Hein on Line Cititation. Cordozo J Int'l \& Comp L.

Lodra, I. N. (2012). Perlindungan Pengetahuan Tradisional dan Praktek HKI, Surabaya. Urna Jurnal Seni Rupa, $1(1)$.

Merryman, J. H. (1996). Two Ways of Thinking about Cultural Property. The American Journal of International Law, 80(4).

Mulyana, D. (2006). Komunikasi Antar Budaya: Paduan Berkomunikasi Dengan Orang-Orang Berbeda Budaya, Remaja Rosdakarya, Bandung.

OK. (2006). Saidin, Aspek Hukum Hak Kekayaan Intelektual (Intellectual Property Right), PT RajaGrafindo Persada, Jakarta.

Payumo, J. G. (2008). Protecting and preserving traditional knowledge and plant genetic resources; is ASEAN there yet? Plant Genetic Resources and Utilization, 8.

Purba, A. (2005). TRIPS- WTO dan Hukum Hak Kekayaan Intelektual Indonesia Kajian Perlindungan Hak Cipta Seni Batik Tradisional, Rineka Cipta, Jakarta.

Rato, D. (2009). Pengantar Hukum Adat, Surabaya, LaksBang Pressindo.

Sardjono, A. (2006). Hak Kekayaan Intelektual dan Pengetahuan Tradisional, Alumni, Bandung.

Syamsuddin, B. A. R. dan M. (2005). Hak Kekayaan Intelektual dan Budaya Hukum. Jakarta: PT Raja Grafindo Persada.

Waager, H. (2008). Biodiversity, Traditional Knowledge and Folklore; work onrelated in IP matters in The WTO, Hein on Line Citation; 3 Intercultural Hum. Rits L. Rev. 215,

Wangkeo, K. (2003). Monumental Challenges: The Lawfulness of Destroying Cultural Heritage During Peacetime. YALE J. INT'L L., 29.

Wangsa, R. (2009). Arti Penting dan Manfaat Perlindungan Hak Cipta bagi Kalangan Pencipta Karya Seni dan Pengusaha Industry Khususnya di Jepara Studi Kasus Ekspresi Budaya Tradisional; Ukiran Jepara, Disajikan dalam Diskusi "Perlindungan Hak Cipta Ukiran Jepara” Jepara 30 Juli.

Warasih, E. (2005). Pranata Hukum Sebuah Telaah Sosiologis, Suryandaru Utama. Semarang.

Widyana, I. M. (1993). Kapita Selekta Hukum Pidana Adat, PT. Eresco Bandung.

\section{Notes}

Note 1. Eva Damayanti, Hukum Merk Tanda Produk Industri Budaya, PT. Alumni, 2002, P.12

Note 2. Koentjoroningrat, Pengantar Ilmu Antropologi, Rineka Cipta, Jakarta, 2009, P.69; T.O. Ikhromi, 
Pokok-Pokok Antropologi Budaya, Jakarta,Yayasan Obor Indonesia, 2010, P. 13

Note 3. Deddy Mulyana, Komunikasi Antar Budaya : Paduan Berkomunikasi Dengan Orang-Orang Berbeda Budaya, Remaja Rosdakarya, Bandung, 2006, P.59.

Note 4. Dominikus Rato, Pengantar Hukum Adat,Surabaya, LaksBang Pressindo, 2009, P.101 ; Hilman Hadikusuma, Pengantar Hukum Adat, Jakarta, Mandar Maju, 2010, P.51.

Note 5. Agus Sardjono,Hak Kekayaan Intelektual dan Pengetahuan Tradisional,Alumni, Bandung,2006, P.35; I Nyoman Lodra, Perlindungan Pengetahuan Tradisional dan Praktek HKI, Surabaya, Urna Jurnal Seni Rupa, Vol 1, No.1, 2012, P.11; Budi Agus Riswandi dan M. Syamsuddin. Hak Kekayaan Intelektual dan Budaya Hukum. Jakarta: PT Raja Grafindo Persada, 2005, P.34

Note 6. Cita Citrawinda, Hak Kekayaan IIntelektual- Tantangan Masa Depan, Jakarta Badan Penerbit Fakultas Hukum Universitaas Indonesia, 2003, P.67; David Bainbridge, Intellectual Property, Financial Times, Pitman Publishing, England, 1999, P.111

Note 7. Afrilyana Purba, TRIPS- WTO dan Hukum Hak Kekayaan Intelektual Indonesia Kajian Perlindungan Hak Cipta Seni Batik Tradisional, Rineka Cipta, Jakarta, 2005, P.37; Afifah Kusumadara, Pemeliharaan dan Pelestarian Pengetahuan Tradisional dan Ekspresi Budaya Tradisional Indonesia: Perlindungan Hak Kekayaan Intelektual dan Non-Hak Kekayaan Intelektual, Jurnal Hukum, No.1, Vol 18, 2011, P.11

Note 8. Earl W. Kintner dan Jack Lahr, An Intellectual Property Law Primer, Clark Boardman, New York, 1983,P.111; Eddy Damian, Hukum Hak Cipta, PT Alumni, Bandung, 2009,P.89; Muhammad Djumhana dan R. Djubaedillah, Hak Kekayaan Intellektual, Sejarah, Teori dan Praktiknya di Indonesia,PT. Citra Aditya Abadi, Jakarta, 1997, P.76

Note 9. M.Zulfa Aulia. Perlindungan Hak Kekayaan Intelektual atas Pengetahuan Tradisional. Jakarta: FH UI, 2006, P.68; OK. Saidin, Aspek Hukum Hak Kekayaan Intelektual (Intellectual Property Right), PT RajaGrafindo Persada, Jakarta, 2006, P.78; Silke von Lewinski, Indigeneous Heritage and Intellectual Property: Genetic Resources, Traditional Knowledge and Folklore, Kluwer Law International, 2004, P.116

Note 10. I.Made Widyana,Kapita Selekta Hukum Pidana Adat, PT. Eresco Bandung, 1993,P. 121-122; M.Guntur Hamzah, Peranan Hukum Dalam Upaya Pelestarian Warisan Budaya, Jurnal Ilmu Hukum Amannagappa, Vol 12, No.3, 2004, P.244

Note 11. Esmi Warasih, Pranata Hukum Sebuah Telaah Sosiologis, Suryandaru Utama, Semarang, 2005, P. 60.

Note 12. Hanu Waager, Biodiversity, Traditional Knowledge and Folklore; work onrelated in IP matters in The WTO, Hein On Line Citation; 3 Intercultural Hum. Rits L. Rev. 215, 2008, P.54; Peter Drahos, Thinking strategically about intellectual property rights, World Patent Information, Vol. 29, 2007, P.255-261, Jane G. Payumo, Protecting and preserving traditional knowledge and plant genetic resources; is ASEAN there yet?, Plant Genetic Resources and Utilization, Vol. 8, 2008, P.26-34; Silke Von Lewinski, The Protection Of Folklore, Hein On Line Cititation; 11 Cordozo J Int'l \& Comp L, 2003-2004, P.747; G. Dutfield, Intellectual Property,Biogenetic Resources and Traditional Knowledge, Earthscan, UK, 2004, P.52; G. Dutfield, Protecting The Rights Of Indigenous People; Can Prior Informed Consent Help?, Chapter 4, P.53-67.

Note 13. Wangsa,Rasdi, Arti Penting dan Manfaat Perlindungan Hak Cipta bagi Kalangan Pencipta Karya Seni dan Pengusaha Industry Khususnya di Jepara Studi Kasus Ekspresi Budaya Tradisional; Ukiran Jepara, Disajikan dalam Diskusi "Perlindungan Hak Cipta Ukiran Jepara” Jepara 30 Juli 2009.

Note 14. Rosemary J Coombe, 'Protecting Traditional Environmental Knowledge and New Social Movements in the Americas: Intellectual Property, Human Right, or Claims to an Alternative Form of Sustainable Development?' Florida J Intl L, Vol. 17, No. 115, 2005, P. 115

Note 15. Paul J Heald, 'The Rhetoric of Biopiracy' (2003) 11 Cardozo J Intl \& Comparative L, No. 519, P. 536

Note 16. John Henry Merryman, Two Ways of Thinking About Cultural Property, The American Journal of International Law, Vol. 80, No. 4. Oct., 1986, P. 831-853

Note 17. Maria Aurora Fe Candelaria, The Angkor Sites of Cambodia: The Conflicting Values of Sustainable Tourism and State Sovereignty, 31 BROOK. J. INT'L L. 253, 2005

Note 18. Kanchana Wangkeo, Monumental Challenges: The Lawfulness of Destroying Cultural Heritage During Peacetime, Vol.29 YALE J. INT'L L., 2003, P.183 


\section{Copyrights}

Copyright for this article is retained by the author(s), with first publication rights granted to the journal.

This is an open-access article distributed under the terms and conditions of the Creative Commons Attribution license (http://creativecommons.org/licenses/by/3.0/). 